\title{
Efisiensi Emiten Properti dan Real estate yang Terdaftar di Indeks Saham Syariah Indonesia Tahun 2016-2020
}

\author{
Indah Fresma Sari \\ Departemen Ilmu Ekonomi Syariah Institut Pertanian Bogor \\ indahfresmasari55@gmail.com \\ Jaenal Effendi \\ Departemen Ilmu Ekonomi Syariah Institut Pertanian Bogor \\ jaenfendi@gmail.com
}

\section{Abstract:}

This study aims to analyze the efficiency of property and real estate issuers listed in the Indonesia Sharia Stock Index (ISSI) during 2016-2020 period and the factors that influence it. In the first stage, the researcher analyzes the efficiency value of property and real estate issuers using Data Envelopment Analysis (DEA) method. In the second stage, the researcher analyzes the factors that influence the efficiency value of property and real estate issuers by using tobit regression. There are 16 issuers used in this study. The results showed that none of the issuers consistently achieved the perfect technical efficiency score (the efficiency score is equal to 1) during the study period. The same thing happened to the pure technical efficiency analysis and the efficiency scale results. The results of the tobit model regression showed that the Return on Assets (ROA) has significant positive effect and the exchange rate (LNKURS) has significant negative effect on the efficiency value of property and real estate issuers. Meanwhile, the Debt to Asset Ratio (DAR), company size (LNSIZE), and interest rate (BIRATE) do not have significant effect on the efficiency of property and real estate issuers.

Keywords: Data Envelopment Analysis, efficiency, property and real estate issuers, tobit regression model

\begin{abstract}
Abstrak:
Penelitian ini bertujuan untuk menganalisis efisiensi emiten properti dan real estate yang terdaftar di Indeks Saham Syariah Indonesia (ISSI) selama periode 2016-2020 serta faktor faktor yang memengaruhinya. Pada tahap pertama, peneliti menganalisis nilai efisiensi emiten properti dan real estate dengan menggunakan metode Data Envelopment Analysis (DEA). Pada tahap kedua, peneliti menganalisis faktor-faktor yang memengaruhi nilai efisiensi emiten properti dan real estate dengan menggunakan regresi tobit. Terdapat 16 emiten yang digunakan okdalam penelitian ini. Hasil penelitian menunjukkan bahwa tidak ada satupun emiten yang konsisten mencapai nilai efisiensi teknis sempurna (skor efisiensi sama dengan 1) selama periode penelitian. Hal serupa juga terjadi pada hasil analisis efisiensi teknis murni maupun skala efisiensi. Hasil regresi model tobit menunjukkan bahwa Return on Asset (ROA) yang berpengaruh positif secara signifikan dan kurs (LNKURS) berpengaruh negatif secara signifikan terhadap nilai efisiensi emiten properti dan real estate. Sementara itu, Debt to Asset Ratio (DAR), ukuran perusahaan (LNSIZE), dan suku bunga (BIRATE) tidak berpengaruh signifikan tergadap efisiensi emiten properti dan real estate.

Kata kunci: Data Envelopment Analysis, efisiensi, emiten properti dan real estate, regresi model tobit
\end{abstract}




\section{PENDAHULUAN}

Pasar modal memainkan peran yang penting bagi perekonomian suatu negara. Fungsi pasar modal yaitu sebagai sarana penyediaan instrumen atau efek likuiditas dan sebagai sarana yang mendorong unit-unit yang surplus untuk menempatkan dananya dengan berinvestasi di pasar modal. Pasar modal Indonesia terus menunjukkan tren perkembangan. Perkembangan akumulasi modal pada instrumen investasi di pasar modal Indonesia menunjukkan hal tersebut.

\section{Gambar 1.}

\section{Akumulasi Modal Instrumen Investasi Pasar Modal Indonesia (Rp Triliun)}

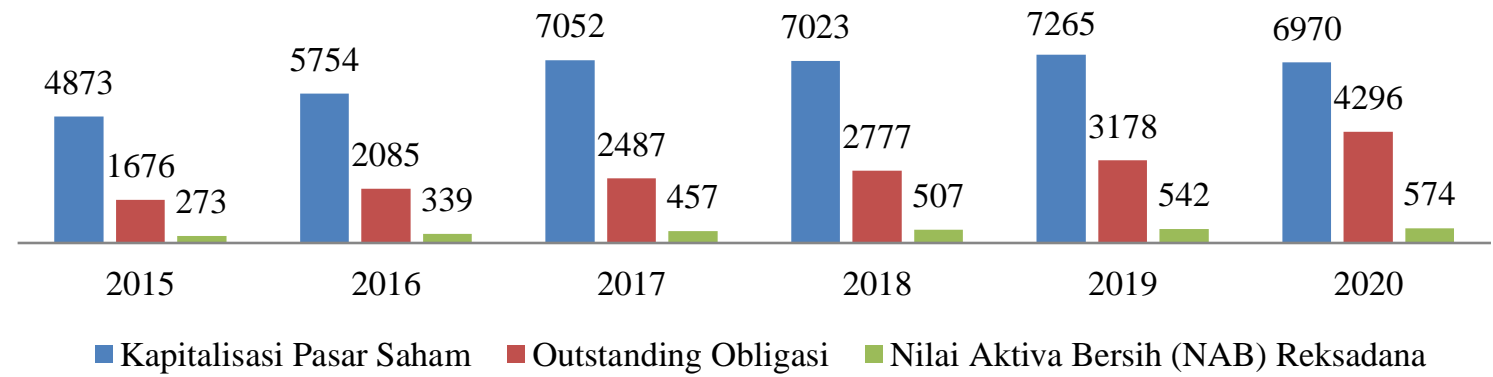

Sumber: BEI dan OJK (2020)

Berdasarkan Gambar 1 kenaikan kapitalisasi pasar saham terjadi pada tahun 2016, 2017, dan 2019. Sebaliknya, pada tahun 2018 dan 2020 kapitalisasi pasar saham mengalami penurunan. Kemudian oustanding value obligasi dan NAB reksadana terus mengalami peningkatan pada tahun 2015 hingga 2020. Berdasarkan gambar tersebut, saham merupakan produk investasi dengan nilai akumulasi modal terbesar dibandingkan produk investasi lain yang tersedia di pasar modal.

Pada pasar modal syariah, saham dalam bentuk saham syariah diterbitkan oleh pihak yang dikenal dengan emiten atau perusahaan publik yang menyatakan bahwa kegiatan, jenis, dan cara pengelolaan usaha sejalan prinsip syariah di pasar modal dalam anggaran dasarnya. ${ }^{1}$ Saham syariah juga diterbitkan oleh emiten atau perusahaan publik yang kegiatan dan jenis usaha, cara pengelolaan, dan/atau jasa yang disediakannya tidak dinyatakan mengikuti aturan terkait prinsip syariah di pasar modal akan tetapi sahamnya memenuhi kriteria saham syariah. $^{2}$

\footnotetext{
${ }^{1}$ OJK, "Peraturan Otoritas Jasa Keuangan Nomor 17/POJK.04/2015 Tentang Penerbitan Persyaratan Efek Syariah Berupa Saham Emiten Syariah,” 2015.

2 OJK, "Peraturan Otoritas Jasa Keuangan Nomor 35/POJK.04/2017 Tentang Kriteria Dan Penerbitan Daftar Efek Syariah,” 2017.
} 
Gambar 2.

Jumlah Emiten ISSI Per Sub Industri di BEI Tahun 2016-2020

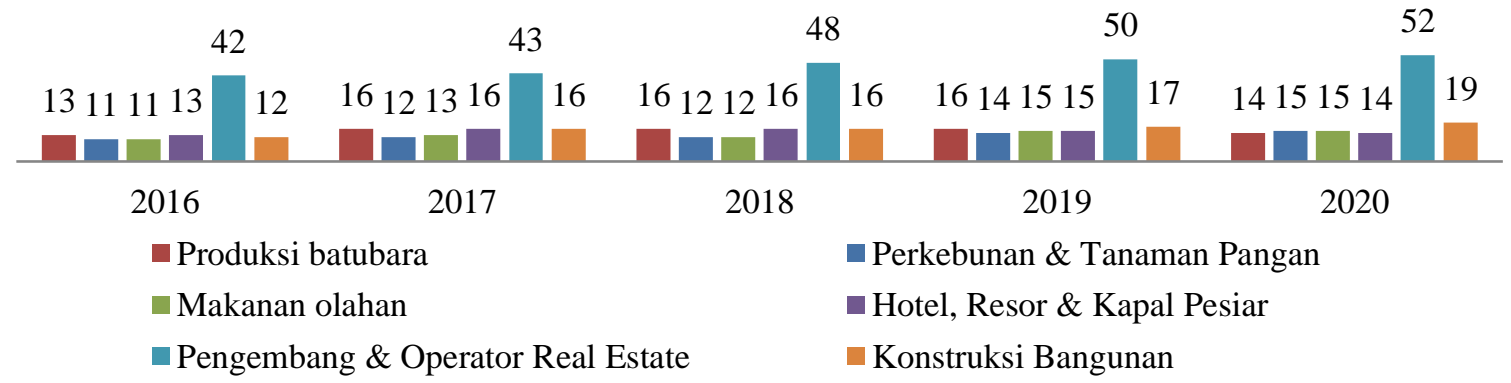

Sumber: BEI (2020)

Gambar 2 menunjukkan enam sub industri dengan emiten terbanyak yang terdaftar di Indeks Saham Syariah Indonesia (ISSI). Emiten dengan jumlah terbanyak di ISSI yaitu emiten yang berada dalam sub industri pengembang dan operator real estate (real estate development and management). Sub industri ini berada dalam sub sektor properti dan real estate (property and real estate). ${ }^{3}$ Jumlah emiten dalam sub industri ini mengalami peningkatan dari tahun 2016 hingga tahun 2020.

Gambar 3.

Kapitalisasi Pasar Sub Sektor Properti dan Real Estate IHSG dan ISSI tahun 2015-2020 (Rp Triliun)

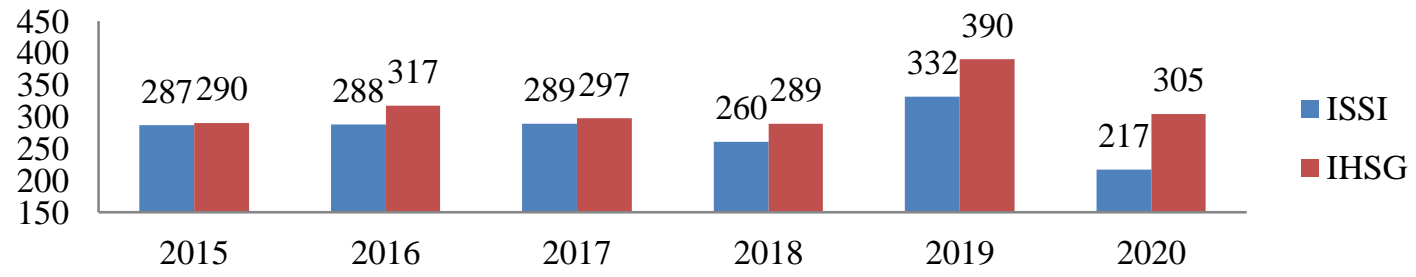

Sumber : BEI (2020)

Berdasarkan Gambar 3 kapitalisasi pasar emiten sektor properti dan real estate yang terdaftar di ISSI memiliki persentase kontribusi yang tinggi terhadap keseluruhan kapitalisai pasar industri real estate di IHSG (Indeks Harga Saham Gabungan). Pada tahun 2015 hingga tahun 2018 persentasenya mencapai lebih dari 90 persen. Pada tahun 2019 dan 2020 persentasenya mencapai 85 persen dan 71 persen.

Berdasarkan Statistik Bursa Efek Indonesia tahun 2015 hingga tahun 2020 sektor properti dan real estate selalu menempati tujuh besar sektor dengan nilai kapitalisasi pasar tertinggi di bursa efek. Pada tahun 2019 industri ini menempati urutan kapitalisasi pasar terbesar kedua setelah industri perbankan yaitu dengan nilai Rp 390 triliun. Pada tahun 2020 industri ini menempati urutan kapitalisasi pasar terbesar keempat setelah industri perbankan, industri makanan dan minuman, dan industri telekomunikasi dengan nilai kapitalisasi mencapai Rp 305 triliun. Sektor properti dan real estate adalah sektor yang berperan penting bagi perekonomian di Indonesia. Sektor ini memiliki rata-rata kontribusi

\footnotetext{
${ }^{3}$ BEI, "Klasifikasi Industri Baru BEI (IDX Industrial Classification),” 2021, https://www.idx.co.id. 80 
sebesar 3 persen terhadap Produk Domestik Bruto (PDB) Indonesia pada tahun 2016 hingga tahun 2020. Laju pertumbuhan sektor ini mencapai 6 persen pada tahun 2019. ${ }^{4}$ Emiten properti dan real estate adalah perusahaan yang berada dalam industri properti dan real estate. Aktivitas perusahaan tersebut adalah melakukan pengembangan, pengoperasian, penjualan, dan penyewaan real estate, misalnya bangunan tempat tinggal seperti apartemen dan perumahan, bangunan non tempat tinggal seperti perkantoran dan pertokoan, tanah pengembangan gedung dan lain sebagainya. ${ }^{5}$

Seberapa baik perusahaan mengelola sumberdaya yang dimilikinya untuk memaksimalkan pendapatan maupun laba akan menentukan kinerja perusahaan tersebut. ${ }^{6}$ Investor seharusnya dapat mengalokasikan dana di perusahaan yang memiliki kinerja yang baik dengan harapan mereka akan menerima nilai tambah dari investasi mereka. Oleh karena itu, mengevaluasi kinerja perusahaan sangat penting bagi investor. Analisis perusahaan yang mengeluarkan saham (emiten) merupakan unsur yang penting karena informasi yang diperoleh dari analisis tersebut dapat mengungkapkan kinerja (performance) perusahaan. ${ }^{7}$ Salah satu cara untuk menilai kinerja suatu perusahaan yaitu dilihat dari efisiensinya. Efisiensi merupakan salah satu masalah utama bagi suatu perusahaan untuk dapat bertahan dalam menghadapi persaingan. Efisensi juga merupakan poin penting untuk menilai kinerja kegiatan perusahaan secara keseluruhan sehingga perusahaan tetap kompetitif di pasar ${ }^{8}$

Terlebih saat ini Indonesia sedang menghadapi pandemi COVID-19. Di tengah pandemi COVID-19, efisiensi merupakan salah satu isu yang menjadi fokus utama perusahaan perusahaan di Indonesia tak terkecuali perusahaan properti dan real estate. Emiten properti dan real estate yang terdaftar di ISSI melakukan efisiensi pada perusahaannya agar dapat bertahan di masa pandemi. Hal ini sesuai dengan Laporan Informasi atau Fakta Material Survey Dampak COVID-19 yang diterbitkan oleh emiten dan dipublikasikan melalui Bursa Efek Indonesia. Pada sektor properti dan real estate misalnya PT Pakuwon Jati Tbk (PWON) menyatakan bahwa kelangsungan usaha perseoran terganggu akibat COVID-19 dan mengalami penghentian operasional sebagian. Perusahaan melakukan penghentian pada segmen usaha dan bisnis unit. Perusahaan melakukan PHK (Pemutusan Hubugan Kerja) terhadap 58 karyawan dan melakukan pemotongan gaji terhadap 100 karyawan. Strategi yang diupayakan demi mempertahankan usaha di tengah pandemi COVID-19 yaitu melalui pengurangan belanja modal dan beban operasional serta pemberian relaksasi pola pembayaran terhadap tenant-tenant di pusat perbelanjaan yang terkena dampak. ${ }^{9}$ Hal serupa juga terjadi pada PT Lippo Cikarang Tbk (LPCK). Perusahaan ini menyatakan adanya pembatasan operasional pada unit perusahaannya dan melakukan pemotongan gaji terhadap

\footnotetext{
${ }^{4}$ BPS, "Produk Domestik Bruto Indonesia Triwulanan 2016-2020,” 2020, https://www.bps.go.id.

${ }^{5}$ BEI, "Panduan IDX Industrial Classification," 2021, https://www.idx.co.id/.

${ }^{6}$ Tessa V. Soetanto and Liem Pei Fun, "Performance Evaluation of Property and Real Estate Companies Listed on Indonesia Stock Exchange Using Data Envelopment Analysis," Jurnal Manajemen Dan Kewirausahaan 16, no. 2 (2014): 121-29, doi:10.9744/jmk.16.2.121-130.

${ }^{7}$ Edi Wibowo, “Analisis Penentuan Saham Yang Akan Dibeli Suatu Tinjauan Umum,” Jurnal Ekonomi Dan Kewirausahaan 11, no. 1 (2011): 151-58.

8 A. George Assaf, Carlos Barros, and Ricardo Sellers-Rubio, "Efficiency Determinants in Retail Stores: A Bayesian Framework," Omega 39, no. 3 (2011): 283-92, doi:10.1016/j.omega.2010.07.005.

9 Bursa Efek Indonesia, "Laporan Informasi Atau Fakta Material Dampak Pandemi COVID-19 PWON," 2020, https://www.idx.co.id/.
} 
Indah Fresma Sari, Jaenal Effendi

123 karyawannya. Salah satu upaya LPCK untuk bertahan di masa pandemi COVID-19 yaitu melalui efisiensi penggunaan dana terutama pada pos-pos pengeluaran yang strategis. ${ }^{10}$

\section{Gambar 4. \\ Total Asset Turnover Emiten Properti dan Real estate yang Terdaftar di ISSI 2016- 2020}

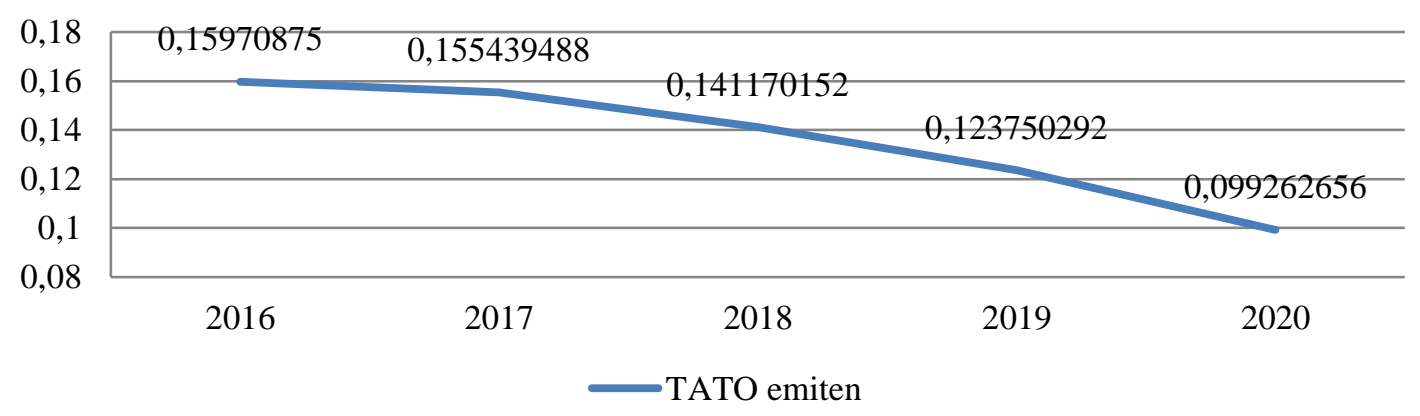

Sumber: Laporan Keuangan Emiten (2020, diolah)

Berdasarkan Gambar 4, Total Asset Turnover (TATO) emiten properti dan real estate yang terdaftar di ISSI terus mengalami penurunan dari tahun 2016 hingga 2020. Penurunan TATO terbesar terjadi pada tahun 2020. Pada tahun 2020, emiten mengalami penurunan sebesar 19,8 persen dari tahun 2019. Penurunan TATO pada perusahaan memberikan gambaran bahwa kemampuan perusahaan untuk menghasilkan penjualan yang lebih tinggi dibandingkan dengan asetnya mengalami penurunan. ${ }^{11}$ Perusahaan harus mengetahui dan memerhatikan penyelenggaraan manajemen dalam perusahaan sehingga perusahaan dapat mengetahui hal yang menyebabkan terjadinya inefisiensi yang berpengaruh terhadap kinerja perusahaan. Pengelolaan yang kurang efektif dan efisien dapat menimbulkan terjadinya inefisiensi. ${ }^{12}$

Pengukuran efisiensi dapat dilihat berdasarkan dua aspek yaitu aspek pengeluaran (output) dan pemasukan (input) perusahaan. ${ }^{13}$ Pengukuran efisiensi dapat dilakukan dengan menggunakan pendekatan frontier (frontier approach) yaitu pengukuran yang berdasarkan kemampuan perusahaan untuk memaksimalkan output atau meminimalkan biaya sebagai unit ekonomi agar tujuan tercapai. ${ }^{14}$ Terdapat dua jenis pendekatan frontier yaitu pendekatan deterministik (deterministic approach) yang tergolong sebagai pendekatan non-parametrik dan pendekatan stokastik (stochastic approach) yang tergolong sebagai pendekatan parametrik. Data Envelopment Analysis (DEA) merupakan pendekatan jenis non parametrik yang sering digunakan dalam efisiensi.

${ }^{10}$ Bursa Efek Indonesia, "Laporan Informasi Atau Fakta Material Dampak Pandemi COVID-19 LPCK," 2020, https://www.idx.co.id/.

${ }^{11}$ Kasmir, Analisis Laporan Keuangan (Jakarta: RajaGrafindo Persada, 2012).

${ }^{12}$ Triyono, "Pengembangan Perusahaan Pada Era Krisis Ekonomi Berkepanjangan," Jurnal Ekonomi Dan Bisnis 2, no. 1 (2005): 1-10.

${ }^{13}$ S A H Mirghaderi et al., "The Ranking of Financial Efficiency of Companies Accepted in Stock Exchange of Tehran between 2013 to 2016 through Financial Ratio Approach and Using DEA" 5, no. 3 (2017).

${ }^{14}$ Wilyanto Kartiko Kusumo and Abdul Karim, "Analisis Efisiensi Perbankan Syariah Dengan Metode Stochastik Frontier Approach (SFA): Studi Kasus Pada Bank Umum Syariah, Unit Usaha Syariah Dan Layanan Syariah (Offece Chanelling) Di Indonesia," SOLUSI 13, no. 2 (2014): 123-51. 
DEA memiliki keunggulan yang membuatnya menjadi alat yang baik untuk mengukur efisiensi perusahaan dibandingkan dengan metode statistik lainnya..$^{15}$ DEA mampu mengelola banyak input dan output terutama dalam ukuran kinerja. DEA tidak memerlukan asumsi suatu hubungan yang fungsional antara input dan output. DEA juga tidak memerlukan kondisi bahwa Decision Making Unit (DMU) untuk mengadopsi bentuk fungsi yang sama. Setiap DMU dapat memaksimalkan efisiensinya dengan menyesuaikan struktur produksinya sendiri. ${ }^{16}$

Penelitian sebelumnya yang mengukur efisiensi emiten properti dan real estate yang terdaftar di BEI menggunakan metode DEA adalah Soetanto dan Fun pada 2014 yang menganalisis efisiensi dari 23 perusahaan properti dan real estate yang terdaftar di BEI periode 2009 hingga 2012 dengan menggunakan DEA. Hasilnya menunjukkan terdapat empat perusahaan yang memiliki skor efisiensi sama dengan 1 pada 2009, enam perusahaan pada 2010 dan 2011, dan sembilan perusahaan pada tahun 2012. Hanya ada satu perusahaan yang konsisten memiliki efisiensi teknis dengan skor efisiensi 1 pada tahun 2009 hingga tahun 2012. Penyebab inefisiensi dari tahun 2009 sampai 2011 adalah inefiensi skala.

Berdasarkan penjelasan di atas, tujuan penelitian ini yaitu menganalisis efisiensi emiten properti dan real estate yang terdaftar pada ISSI tahun 2016-2020 dan menganalisis faktor-faktor yang memengaruhi efisiensi emiten properti dan real estate yang terdaftar pada ISSI tahun 2016-2020. Berbeda dengan penelitian yang dilakukan oleh Soetanto dan Fun tahun 2014, pada penelitian ini penulis menggunakan periode penelitian terbaru yaitu tahun 2016-2020 serta mengembangkan beban pokok penjualan dan total aset sebagai variabel input serta pendapatan sebagai variabel output. Penelitian sebelumnya hanya menganalisis efisiensi emiten properti dan real estate saja, sedangkan pada penelitian ini peneliti jgua melakukan analisis faktor-faktor yang memengaruhi efisiensi emiten properti dan real estate menggunakan metode tobit.

\footnotetext{
${ }^{15}$ Soh Wei Ni, Annuar Md Nassir, and Cheng Fan FAH, "Cash and Profit Efficient in Malaysia and South Korea Listed Company Using Non-Parametric DEA Method and Parametric Regression Method," International Journal of Economics and Management 12, no. Special Issue 2 (2018): 711-29.

${ }^{16} \mathrm{Zhi} \mathrm{Xu}$ and Ping Shi, "Evaluation of Relative Efficiency of Science and Technology Input in China Based on DEA," Studies in Science of Science 23, no. 4 (2005): 481-84.
} 


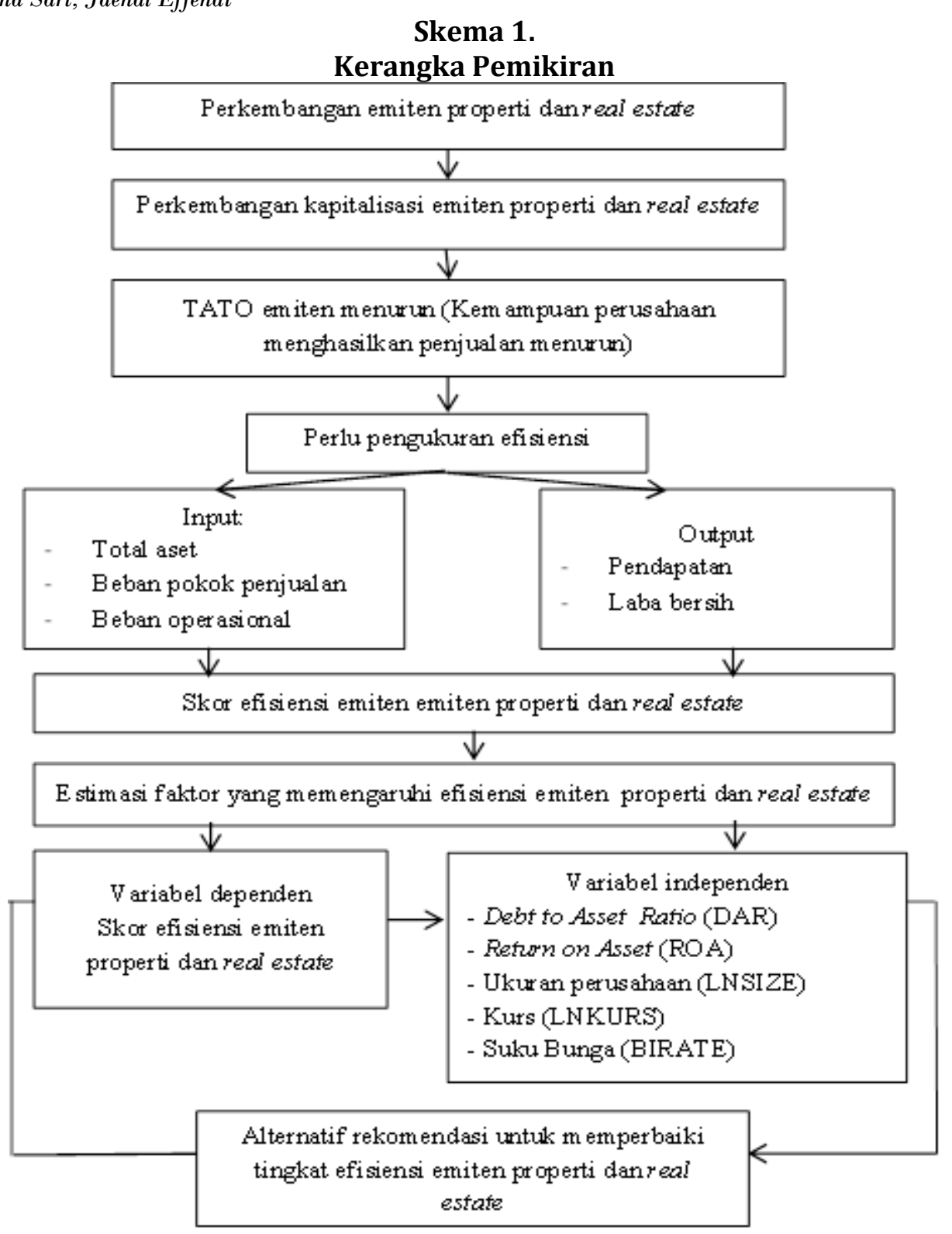

\section{METODE PENELITIAN}

Data sekunder berupa data panel digunakan pada penelitian ini. Data penelitian berasal dari laporan-laporan yang dipublikasikan dalam BEI dan laporan keuangan masingmasing perusahaan yang tersedia di website perusahaan. Sumber lain dalam penelitian ini diperoleh dari jurnal, buku, skripsi, lembaga terkait, literatur terkait dan juga media internet yang berkaitan dengan penelitian.

Populasi pada penelitian ini adalah emiten sektor properti dan real estate yang terdaftar dalam ISSI. Teknik penarikan sampel pada penelitian ini menggunakan teknik purposive sampling. Kriteria yang digunakan dalam penarikan sampel yaitu emiten properti dan real estate di ISSI yang tidak delisting selama periode 2016-2020 dan menyediakan laporan keuangan pada periode tersebut serta memiliki nilai variabel input dan outputnya 
yang bernilai positif. Berdasarkan kriteria tersebut terdapat 16 emiten yang memenuhi kriteria.

Tabel 1.

Daftar Emiten Properti dan Real Estate ISSI Periode 2016-2020

\begin{tabular}{lll}
\hline No & Kode emiten & Nama Penerbit Efek \\
\hline 1 & BCIP & PT. Bumi Citra Permai Tbk \\
2 & BSDE & PT. Bekasi Fajar Industrial Estate Tbk. \\
3 & CTRA & PT. Ciputra Development Tbk. \\
4 & DILD & PT. Intiland Development Tbk. \\
5 & DMAS & PT. Pura Delta Lestari Tbk. \\
6 & DUTI & PT. Duta Pertiwi Tbk. \\
7 & GPRA & PT. Perdana Gapura Prima Tbk. \\
8 & GWSA & PT Greenwood Sejahtera Tbk. \\
9 & INPP & PT. Indonesian Paradise Property Tbk. \\
10 & JRPT & PT. Jaya Real Property Tbk. \\
11 & LPCK & PT. Lippo Cikarang Tbk. \\
12 & MKPI & PT. Metropolitan Kentjana Tbk. \\
13 & MTLA & PT. Metropolitan Land Tbk. \\
14 & PPRO & PT. PP Properti Tbk. \\
15 & PWON & PT. Pakuwon Jati Tbk. \\
16 & SMRA & PT. Summarecon Agung Tbk. \\
\hline
\end{tabular}

Sumber: BEI (2016-2020)

DEA merupakan metode kuantitatif yang digunakan dalam penelitian. Metode DEA digunakan dalam pengukuran nilai efisiensi emiten properti dan real estate di ISSI. Selain itu, penggunaan regresi tobit pada penelitian ini bertujuan guna mengetahui faktor apa saja yang memengaruhi nilai efisiensi tersebut. MaxDEA, Microsoft Excel 2010 dan Eviews 10 adalah perangkat lunak yang digunakan pada analisis ini. Pendekatan berorientasi input dengan model BCC digunakan pada penelitian ini. Hasil analisis DEA dibuat efisiensi skor antara 0 sampai 1 dan merupakan tingkat efisiensi yang diperoleh dari entitas yang dinilai. ${ }^{17}$ Emiten properti dan real estate akan dinilai efisien jika mendekati nilai 1 dan tidak efisien jika mendekati nilai 0 . Terdapat 3 variabel input dan 2 variabel output yang digunakan pada penelitian ini. Input yang digunakan berupa total aset, beban operasional, dan beban pokok penjualan. Sedangkan variabel output yang digunakan yaitu pendapatan dan laba bersih.

Peneliti menggunakan metode tobit pada penelitian ini karena metode ini dapat menggambarkan hubungan variabel dependen dan variabel independen bersifat kategori, kontinu atau kombinasinya. Metode ini digunakan setelah skor efisiensi telah diketahui. Skor efisiensi yang berada pada rentang nilai 0-1 menjadikan metode ini baik untuk mengestimasi koefisien regresi dalam penganalisisan faktor yang mempengaruhi kinerja efisiensi emiten properti dan real estate. Berikut ini model tobit yang digunakan:

$$
\text { TEit }=b 0+B 1 X 1 i t+B 2 X 2 i t+B 3 \operatorname{LnX} X i t+B 4 \operatorname{LnX} 4 i t+B 5 X 5 i t+e i t
$$

\footnotetext{
${ }^{17}$ William W Cooper, Lawrence M Seiford, and Kaoru Tone, Introduction to Data Envelopment Analysis and Its Uses: With DEA-Solver Software and References, 1st ed. (New York: Springer, 2006), doi:10.1007/0387-29122-9.
} 
Indah Fresma Sari, Jaenal Effendi

Keterangan :

Teit : Skor efisiensi teknis emiten properti dan real estate ke-i pada periode ke-t

b0 : Intercept

Bn : Koefisien variabel ke-n

X1it : Debt to Asset Ratio (DAR) ke-i pada periode ke-t

X2it : Return on Asset (ROA) ke-i pada periode ke-t

X3it : Logaritma natural total aset (LNSIZE) ke-i pada periode ke-t

X4it : Logaritma natural kurs (LNKURS) ke-i pada periode ke-t

X5it : Suku bunga (BIRATE) ke-i pada periode ke-t

eit : Galat

Tabel 2

Definisi Variabel Operasional

\begin{tabular}{|c|c|c|c|}
\hline Variabel & Definisi & Sumber & Rujukan \\
\hline Total Aset & $\begin{array}{l}\text { Jumlah dari keseluruhan aset lancar dan } \\
\text { tidak lancar seperti kas, persediaan, } \\
\text { total piutang, total investasi dan } \\
\text { pembiayaan serta jumlah dari aset } \\
\text { lainnya. }\end{array}$ & $\begin{array}{l}\text { Neraca } \\
\text { Keuangan }\end{array}$ & $\begin{array}{l}\text { (Abdullah, Maamor, } \\
\text { Karim 2020), (Chen dan } \\
\text { Li 2017), (Dou et al. } \\
\text { 2019), (Wang, Nguyen, } \\
\text { dan Dang 2021), (Atta } \\
\text { Mills et al. 2020). }\end{array}$ \\
\hline $\begin{array}{l}\text { Beban } \\
\text { operasional }\end{array}$ & $\begin{array}{l}\text { Keseluruhan biaya yang berhubungan } \\
\text { dengan kegiatan utama perusahaan. } \\
\text { Termasuk di dalamnya adalah beban } \\
\text { penjualan dan beban umum dan } \\
\text { administrasi. }\end{array}$ & $\begin{array}{l}\text { Laporan } \\
\text { Laba Rugi }\end{array}$ & $\begin{array}{l}\text { (Soetanto dan Fun } \\
\text { (2014), (Chen dan Li } \\
\text { (2017), (Zheng, Chau, } \\
\text { dan Hui 2011), Dou et } \\
\text { al. 2019), Atta Mills et } \\
\text { al. 2020). }\end{array}$ \\
\hline $\begin{array}{l}\text { Beban } \\
\text { pokok } \\
\text { penjualan }\end{array}$ & $\begin{array}{l}\text { Beban pokok penjualan adalah beban } \\
\text { pokok produksi yang meliputi biaya } \\
\text { bahan baku, biaya tenaga kerja, dan } \\
\text { biaya overhead yang dikeluarkan oleh } \\
\text { perusahaan untuk memperoleh barang } \\
\text { atau jasa yang dijual kepada konsumen. }\end{array}$ & $\begin{array}{l}\text { Laporan } \\
\text { Laba Rugi }\end{array}$ & $\begin{array}{l}\text { (Wang, Nguyen, dan } \\
\text { Dang 2021). }\end{array}$ \\
\hline Pendapatan & $\begin{array}{l}\text { Penghasilan perusahaan akibat } \\
\text { penjualan produk perusahaan dalam } \\
\text { rangka kegiatan usaha atau aktivitas } \\
\text { perusahaan. }\end{array}$ & $\begin{array}{l}\text { Laporan } \\
\text { Laba Rugi }\end{array}$ & $\begin{array}{l}\text { (Abdullah, Maamor, } \\
\text { Karim 2020), (Chen dan } \\
\text { Li (2017), (Zheng, Chau, } \\
\text { dan Hui 2011), Atta } \\
\text { Mills et al. 2020). }\end{array}$ \\
\hline Laba bersih & $\begin{array}{l}\text { Selisih laba operasi dikurangi dengan } \\
\text { biaya pajak. Laba bersih } \\
\text { merepresentasikan keuntungan atau } \\
\text { laba setelah semua pendapatan dan } \\
\text { beban dalam periode berjalan. }\end{array}$ & $\begin{array}{l}\text { Laporan } \\
\text { Laba Rugi }\end{array}$ & $\begin{array}{l}\text { (Soetanto dan Fun } \\
\text { (2014), (Dou et al. } \\
\text { 2019), (Zheng, Chau, } \\
\text { dan Hui 2011). }\end{array}$ \\
\hline $\begin{array}{l}\text { Debt to } \\
\text { Asset Ratio }\end{array}$ & $\begin{array}{l}\text { Rasio antara total hutang dengan total } \\
\text { aset. }\end{array}$ & $\begin{array}{l}\text { Laporan } \\
\text { Keuangan }\end{array}$ & $\begin{array}{l}\text { (Chen dan Li (2017), } \\
\text { (Atta Mills et al. 2020) }\end{array}$ \\
\hline $\begin{array}{l}\text { Retun on } \\
\text { Asset }\end{array}$ & $\begin{array}{l}\text { Rasio laba sesudah pajak dengan total } \\
\text { aset. }\end{array}$ & $\begin{array}{l}\text { Laporan } \\
\text { Keuangan }\end{array}$ & $\begin{array}{l}\text { (Abdullah, Maamor, } \\
\text { Karim 2020), (Atta Mills } \\
\text { et al. 2020). }\end{array}$ \\
\hline Ukuran & Logaritma natural dari total aset. & Laporan & (Atta Mills et al. 2020), \\
\hline
\end{tabular}


Efisiensi Emiten Properti dan Real Estate yang terdaftar di Indeks Saham Syariah Indonesia Tahun 2016-2020

perusahaan

Kurs

Suku bunga
Nilai tukar mata uang rupiah terhadap mata uang asing.

Persentase beban biaya tertentu dalam rangka peminjaman uang dalam jangka waktu tertentu
Keuangan

BI

BI
(Ni, Nassir, dan FAH

2018).

(Suyati 2015)

(Widhiatmoko dan Dillak 2018)

\section{HASIL DAN PEMBAHASAN}

Berdasarkan hasil pengolahan data laporan keuangan 16 emiten properti dan real estate pada ISSI tahun 2016 hingga 2020 dengan metode DEA (menggunakan model BCC orientasi input), didapatkan tingkat efisiensi yang dinilai dengan 3 penilaian, yaitu efisiensi teknis, efisiensi teknis murni, dan skala efisiensi. Tercapai atau tidaknya efisiensi kinerja perusahaan disebabkan karena adanya kesalahan dalam mengelola input dan outputnya. Hal tersebut dapat terlihat ketika nilai efisiensi teknis murni (PTE) lebih tinggi daripada nilai skala efisiensinya (ES). Akan tetapi, apabila hasil menunjukkan bahwa nilai PTE lebih rendah daripada nilai ES, maka kemungkinan penyebab terjadinya inefisiensi adalah perusahaan tengah berada pada kondisi yang tidak menguntungkan. ${ }^{18}$

\section{Tabel 3.}

Efisiensi Emiten Properti dan Real estate Pada ISSI Tahun 2016-2020

\begin{tabular}{lcccccc}
\hline Emiten properti dan real & \multicolumn{5}{c}{ Efisiensi Teknis } & Rata- \\
\cline { 2 - 6 } \multicolumn{1}{c}{ estate } & 2016 & 2017 & 2018 & 2019 & 2020 & Rata \\
\hline Efisiensi teknis & 0.87 & 0.84 & 0.83 & 0.77 & 0.72 & 0.81 \\
Efisiensi teknis murni & 0.91 & 0.88 & 0.88 & 0.84 & 0.80 & 0.86 \\
Skala efisiensi & 0.96 & 0.95 & 0.94 & 0.93 & 0.91 & 0.94 \\
\hline
\end{tabular}

Sumber: Output DEA (2021, diolah)

Berdasarkan Tabel 3 dapat dilihat bahwa pada tahun 2016-2020 emiten properti dan real estate yang masuk ISSI memiliki rata-rata nilai efisiensi teknis (TE) 0.81, efisiensi teknis murni (PTE) bernilai 0.86, dan skala efisiensi (ES) bernilai 0.94. Nilai SE tersebut lebih besar daripada nilai PTE. Hal tersebut mengungkapkan bahwa sebagian besar emiten masih belum dapat menggunakan kombinasi inputnya berupa total aset, beban pokok penjualan, dan beban operasional untuk menghasilkan output berupa pendapatan dan laba bersih.

Penggunaan metode DEA juga ditujukan untuk menganalisis bagaimana usaha perusahaan untuk meningkatkan kapasitas operasional perusahaannya untuk mencapai kinerja yang optimal. Pada tahap ini, tiap DMU (Decision Making Unit) berada pada salah satu diantara tiga keadaan yaitu Increasing Return to Scale (IRS), Constant Return to Scale (CRS), dan Decreasing Return to Scale (DRS). Pengklasifikasian keadaan tersebut didasarkan pada nilai skala efisiensi (ES) masing-masing perusahaan. Ketika perusahaan memiliki nilai TE, PTE dan ES sama dengan nilai satu, perusahaan tersebut berada pada keadaan Constant to Scale (CRS). Ketika nilai ES perusahaan sama dengan satu namun nilai TE dan PTE kurang dari satu, perusahaan tersebut berada pada keadaan Decreasing to Scale (DRS), sedangkan

18 Ibid. 
Indah Fresma Sari, Jaenal Effendi

apabila nilai ES kurang dari satu maka perusahaan berada pada keadaan Increasing to Scale (IRS). ${ }^{19}$

\section{Gambar 5. \\ Kondisi Return To Scale (RTS)}

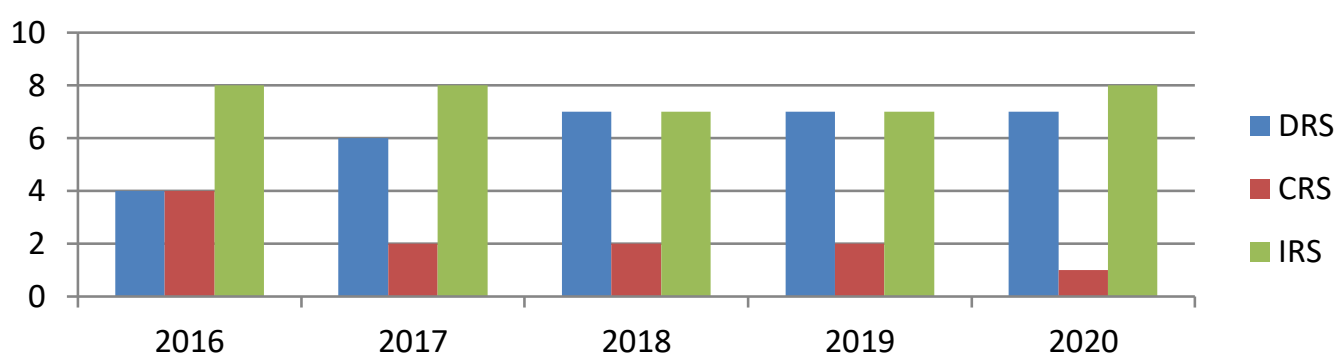

Sumber: Output DEA (2021, diolah)

Berdasarkan Gambar 5 disimpulkan bahwa terdapat 31 emiten yang mengalami kondisi DRS, 11 emiten mengalami CRS dan 38 emiten berada mengalami IRS. Kondisi DRS terjadi saat kenaikan output yang dihasilkan lebih kecil daripada input yang ditambahkan. Pada kondisi tersebut perusahaan diharuskan untuk meminimalisasi input karena tidak idealnya jumlah input dan output yang dihasilkan. Sementara itu, kondisi CRS terjadi ketika penambahan input akan menaikkan output yang sebanding dengan penambahan input. Kondisi ini merupakan kondisi ideal. Sedangkan IRS terjadi ketika penambahan input akan menaikkan output lebih besar daripada penambahan input. Kondisi ini memungkinkan perusahaan untuk meningkatkan kapasitas output dengan mempertahankan input yang tersedia.

Tabel 4.

Tingkat Efisiensi Teknis Emiten Properti dan Real estate Pada ISSI Tahun 2016-2020

\begin{tabular}{lcccccc}
\hline \multirow{2}{*}{ Kode emiten } & \multicolumn{5}{c}{ Efisiensi Teknis (TE) } & \multirow{2}{*}{ Rata-Rata } \\
\cline { 2 - 5 } & 2016 & 2017 & 2018 & 2019 & 2020 & \\
\hline BCIP & 0.92 & 0.96 & 0.87 & 0.66 & 0.60 & 0.80 \\
BSDE & 0.88 & 0.92 & 0.81 & 0.83 & 0.78 & 0.84 \\
CTRA & 0.72 & 0.66 & 0.68 & 0.66 & 0.60 & 0.66 \\
DILD & 0.65 & 0.63 & 0.61 & 0.57 & 0.63 & 0.62 \\
DMAS & 1.00 & 0.87 & 0.72 & 1.00 & 0.87 & 0.89 \\
DUTI & 1.00 & 1.00 & 1.00 & 0.88 & 0.90 & 0.96 \\
GPRA & 0.80 & 0.78 & 0.80 & 0.81 & 0.76 & 0.79 \\
GWSA & 0.93 & 0.80 & 0.81 & 0.57 & 0.70 & 0.76 \\
INPP & 0.68 & 0.71 & 0.71 & 1.00 & 0.57 & 0.73 \\
JRPT & 0.96 & 0.90 & 0.83 & 0.83 & 0.80 & 0.86 \\
LPCK & 0.86 & 0.74 & 1.00 & 0.62 & 0.61 & 0.77 \\
MKPI & 1.00 & 1.00 & 0.96 & 0.78 & 0.62 & 0.87
\end{tabular}

19 Mustica Bintang Sabiti, Jaenal Effendi, and Tanti Novianti, "Efisiensi Asuransi Syariah Di Indonesia Dengan Pendekatan Data Envelopment Analysis,” Al-Muzara'ah 5, no. 1 (2018): 69-87, doi:10.29244/jam.5.1.69-87. 
Efisiensi Emiten Properti dan Real Estate yang terdaftar di Indeks Saham Syariah Indonesia Tahun 2016-2020

\begin{tabular}{lllllll} 
MTLA & 0.91 & 0.85 & 0.91 & 0.74 & 0.66 & 0.81 \\
PPRO & 1.00 & 0.94 & 0.83 & 0.69 & 1.00 & 0.89 \\
PWON & 0.91 & 0.92 & 0.97 & 0.96 & 0.76 & 0.90 \\
SMRA & 0.73 & 0.72 & 0.74 & 0.78 & 0.65 & 0.72 \\
\hline
\end{tabular}

Sumber: Output DEA (2021, diolah).

Perusahaan properti dan real estate dapat dikatakan baik dan memiliki kinerja yang efisien jika perusahaan tersebut dapat mengelola input dan menghasilkan output yang optimal dalam berbagai keadaan pasar yang dihadapi. Pada Tabel 4 terlihat bahwa belum ada emiten yang beroperasi secara efisien karena tidak ada emiten yang secara konsisten memiliki skor efisiensi dengan nilai 1 sejak tahun 2016 hingga 2020. DUTI memiliki rata-rata efisiensi teknis tertinggi mencapai 0.96 . Emiten properti dan real estate yang memiliki ratarata efisiensi teknis terendah adalah DILD dengan skor efisiensi hanya mencapai 0.62 .

Tabel 5.

Tingkat Efisiensi Teknis Murni Emiten Properti dan Real estate Pada ISSI Tahun 20162020

\begin{tabular}{lcccccc}
\hline \multirow{2}{*}{ Kode emiten } & \multicolumn{9}{c}{ Efisiensi Teknis Murni (PTE) } & \multirow{2}{*}{$\begin{array}{c}\text { Rata- } \\
\text { Rata }\end{array}$} \\
\cline { 2 - 6 } & 2016 & 2017 & 2018 & 2019 & 2020 & \\
\hline BCIP & 1.00 & 1.00 & 1.00 & 0.94 & 1.00 & 0.99 \\
BSDE & 1.00 & 1.00 & 0.99 & 0.97 & 0.88 & 0.97 \\
CTRA & 0.78 & 0.72 & 0.74 & 0.72 & 0.63 & 0.72 \\
DILD & 0.65 & 0.63 & 0.63 & 0.57 & 0.64 & 0.62 \\
DMAS & 1.00 & 0.92 & 0.79 & 1.00 & 0.90 & 0.92 \\
DUTI & 1.00 & 1.00 & 1.00 & 0.88 & 0.90 & 0.96 \\
GPRA & 0.82 & 0.80 & 0.82 & 0.83 & 0.78 & 0.81 \\
GWSA & 1.00 & 1.00 & 1.00 & 0.82 & 1.00 & 0.96 \\
INPP & 0.82 & 0.82 & 0.80 & 1.00 & 0.67 & 0.82 \\
JRPT & 0.96 & 0.90 & 0.83 & 0.84 & 0.81 & 0.87 \\
LPCK & 0.86 & 0.74 & 1.00 & 0.62 & 0.62 & 0.77 \\
MKPI & 1.00 & 1.00 & 0.96 & 0.79 & 0.64 & 0.88 \\
MTLA & 0.92 & 0.86 & 0.91 & 0.75 & 0.69 & 0.83 \\
PPRO & 1.00 & 1.00 & 0.83 & 0.72 & 1.00 & 0.91 \\
PWON & 0.94 & 0.95 & 1.00 & 1.00 & 0.80 & 0.94 \\
SMRA & 0.78 & 0.81 & 0.79 & 1.00 & 0.76 & 0.83 \\
\hline
\end{tabular}

Sumber: Output DEA (2021, diolah)

Tabel 5 menunjukkan tentang tingkat efisiensi teknis murni emiten properti dan real estate yang didapatkan dari hasil kombinasi input dan outputnya. Berdasarkan tabel tersebut, secara keseluruhan belum ada emiten properti dan real estate yang memiliki kinerja yang efisien. Skor efisiensi teknis murni tertinggi dimiliki oleh BCIP yang mencapai 0.99, kemudian disusul oleh BSDE dengan skor 0.97. Sedangkan skor efisiensi teknis murni terendah dimiliki oleh DILD yang hanya mencapai 0.62 . Kemudian disusul oleh CTRA dengan skor efisiensi teknis murni 0.72 .

Tabel 6. 
Indah Fresma Sari, Jaenal Effendi

Tingkat Skala Efisiensi Emiten Murni Properti dan Real estate Pada ISSI Tahun 20162020

\begin{tabular}{lcccccc}
\hline \multirow{2}{*}{ Kode emiten } & \multicolumn{5}{c}{ Skala Efisiensi (SE) } & \multirow{2}{*}{ Rata-Rata } \\
\cline { 2 - 6 } & 2016 & 2017 & 2018 & 2019 & 2020 & \\
\hline BCIP & 0.92 & 0.96 & 0.87 & 0.71 & 0.60 & 0.812 \\
BSDE & 0.88 & 0.92 & 0.82 & 0.86 & 0.88 & 0.872 \\
CTRA & 0.92 & 0.92 & 0.92 & 0.92 & 0.95 & 0.926 \\
DILD & 1.00 & 1.00 & 0.97 & 1.00 & 0.99 & 0.992 \\
DMAS & 1.00 & 0.94 & 0.92 & 1.00 & 0.96 & 0.964 \\
DUTI & 1.00 & 1.00 & 1.00 & 0.99 & 1.00 & 0.998 \\
GPRA & 0.98 & 0.97 & 0.98 & 0.98 & 0.97 & 0.976 \\
GWSA & 0.93 & 0.80 & 0.81 & 0.69 & 0.70 & 0.786 \\
INPP & 0.83 & 0.87 & 0.89 & 1.00 & 0.85 & 0.888 \\
JRPT & 1.00 & 1.00 & 1.00 & 0.99 & 0.99 & 0.996 \\
LPCK & 1.00 & 1.00 & 1.00 & 1.00 & 0.99 & 0.998 \\
MKPI & 1.00 & 1.00 & 1.00 & 0.99 & 0.98 & 0.994 \\
MTLA & 0.99 & 0.99 & 1.00 & 0.99 & 0.97 & 0.988 \\
PPRO & 1.00 & 0.94 & 0.99 & 0.96 & 1.00 & 0.978 \\
PWON & 0.97 & 0.97 & 0.97 & 0.96 & 0.96 & 0.966 \\
SMRA & 0.94 & 0.89 & 0.93 & 0.78 & 0.86 & 0.880 \\
\hline
\end{tabular}

Sumber: Output DEA (2021, diolah)

Berdasarkan Tabel 6, secara keseluruhan belum ada emiten properti dan real estate yang konsisten mempunyai skor skala efisiensi sama dengan 1. Skor sakla efisiensi tertinggi dimiliki oleh DUTI dan LPCK yang mencapai 0.998, kemudian disusul oleh JRPT dengan skor 0.996. Sedangkan skor skala efisiensi terendah dimiliki oleh GWSA yang hanya mencapai 0.786. Kemudian disusul oleh BCIP dengan skor skala efisiensi sebesar 0.812 .

\section{Gambar 6.}

\section{Peringkat 10 besar emiten properti dan real estate yang menjadi rujukan}

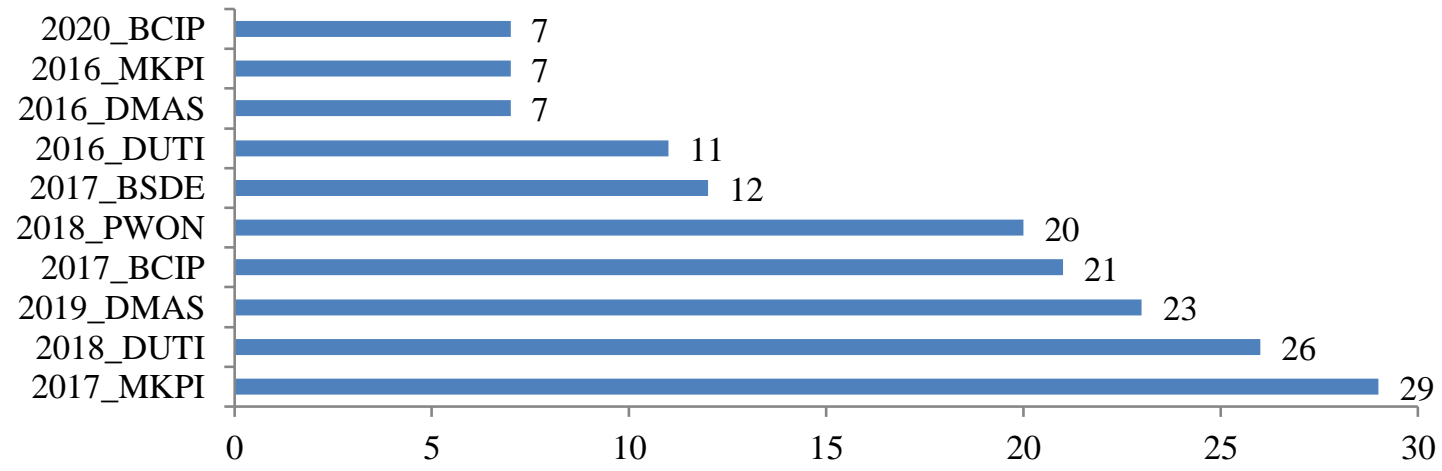

Sumber: Output DEA (2021, diolah)

Selain digunakan untuk mengukur skor efisiensi dan Return To Scale (RTS), metode DEA juga dapat digunakan untuk melihat perusahaan mana yang menjadi rujukan atau referensi bagi emiten properti dan real estate yang belum efisien (benchmarking). Gambar 6 
menunjukkan peringkat 10 besar frekuensi emiten properti dan real estate yang menjadi rujukan emiten properti dan real estate yang belum efisien. Dari hasil perhitungan analisis frontier menunjukkan bahwa emiten yang paling banyak dirujuk adalah MKPI tahun 2017 yang dirujuk oleh 29 DMU. Kemudian DUTI tahun 2018 menjadi unit usaha peringkat kedua yang dirujuk sebanyak 26 DMU. Sementara DMAS tahun 2019 telah dirujuk sebanyak 23 DMU.

Berdasarkan hasil benchmarking, tiap DMU yang mengalami inefisiensi dapat mengetahui besar potensi perbaikan (potential improvement). Persentase yang diperoleh dari kombinasi rata-rata target penggunaan input dan output dengan rata-rata penggunaan aktual input dan output masing-masing unit disebut dengan potential improvement. Nilai potential improvement pada seluruh emiten properti dan real estate yang dijelaskan oleh tabel 7.

Tabel 7.

Potential Improvement emiten properti dan real estate pada ISSI tahun 2016-2020

\begin{tabular}{lrrr}
\hline \multirow{2}{*}{ Variabel } & \multicolumn{2}{c}{ Rata-Rata (Jutaan rupiah) } & \multirow{2}{*}{ Persen (\%) } \\
\cline { 2 - 3 } & \multicolumn{1}{c}{ Aktual } & Target & -20.97 \\
Total aset & 14.058 .565 & 11.111 .034 & -16.40 \\
Beban pokok penjualan & 846713 & 707.884 & -25.68 \\
Beban operasional & 385.340 & 306.121 & 0.00 \\
Pendapatan & 1.852 .065 & 1.852 .065 & 40.81 \\
Laba bersih & 620711 & 874.003 & \\
\hline
\end{tabular}

Sumber: Output DEA (2021, diolah)

Emiten properti dan real estate belum dapat mencapai efisiensi akibat pemakaian input yang berlebihan atau kurang optimalnya output yang dihasilkan. Apabila peneliti ingin mengetahui variabel yang menyebabkan emiten properti dan real estate mengalami inefisiensi, maka peneliti dapat melihat Tabel 7. Tabel tersebut menunjukkan bahwa penyebab inefisiensi paling tinggi selama tahun 2016-2020 adalah variabel beban operasional. Beban operasional atau beban usaha adalah beban kegiatan utama emiten properti dan real estate. Beban operasional tersebut meliputi beban penjualan, beban distribusi, beban umum dan admnistrasi, serta beban operasional lainnya. Emiten properti dan real estate telah mengeluarkan beban operasional yang melebihi target yaitu mencapai 25.68 persen. Upaya yang dapat dilakukan oleh emiten properti dan real estate untuk mengoptimalkan beban operasional yang dikeluarkan adalah melalui efisiensi biaya operasional misalnya meminimalisir biaya-biaya yang tidak urgent serta melakukan kegiatan promosi iklan dan pemasaran yang efektif dan efisien termasuk dalam hal biaya.

Penyebab inefisiensi terbesar kedua yaitu total aset. Total aset ini terdiri dari aset lancar seperti kas, piutang usaha, aset keuangan lancar lainnya serta aset tidak lancar seperti persediaan, properti investasi, aset tetap, dan aset tidak lancar lainnya. Penggunaan aset pada emiten properti dan real estate melebihi target yang dibutuhkan yaitu sebesar 20.97 persen. Hal ini menyebabkan ketidakefisienan input total aset pada emiten properti dan real estate. Upaya yang dapat dilakukan adalah dengan mengelola aset secara optimal, menjaga ketersediaan arus kas supaya cukup untuk pembiayaan kebutuhan operasional dan pembayaran kewajiban pinjaman bank, dan fokus terhadap pengembangan lahan yang telah dimiliki.

Penyebab inefisiensi terbesar ketiga yaitu beban pokok penjualan. Beban pokok penjualan adalah beban persediaan yang ditetapkan sebagai beban sepanjang periode yaitu 
Indah Fresma Sari, Jaenal Effendi

mencakup biaya yang telah diperhitungkan dalam pengukuran persediaan yang telah terjual, overhead produksi yang tidak teralokasi, dan jumlah biaya produksi persediaan. Beban ini meliputi seluruh biaya langsung yang dikeluarkan oleh perusahaan untuk memperoleh barang atau jasa yang akan ditawarkan kepada konsumen. Emiten properti dan real estate telah mengeluarkan beban operasional yang melebihi target yaitu mencapai 16.40 persen. Upaya yang dapat dilakukan oleh emiten properti dan real estate untuk mengoptimalkan beban pokok penjualan adalah melakukan pengelolaan beban pokok penjualan yang meliputi pengeluaran untuk biaya overhead, biaya tenaga kerja, dan biaya bahan baku.

Berdasarkan penjelasan tersebut, dapat diambil kesimpulan bahwa penyebab terjadinya inefisiensi emiten properti dan real estate terdapat pada semua variabel input yang digunakan dalam penelitian ini. Sementara itu pendapatan emiten sudah sesuai dengan target namun laba bersih emiten masih dapat diupayakan untuk dioptimalkan. Laba bersih yang diperoleh oleh emiten properti dan real estate belum sesuai dengan jumlah yang ditargetkan Upaya yang dapat dilakukan oleh emiten untuk mengoptimalkan laba bersih adalah melalui efisiensi biaya produksi dan biaya operasional, pengendalian arus kas dengan pengurangan beban operasional dan pengurangan belanja modal (capex), dan pengajuan keringanan bunga bank, dan permohonan keringanan pajak.

Metode tobit merupakan metode untuk menganalisis faktor-faktor yang memengaruhi efisiensi emiten properti dan real estate. Pada analisis ini, debt to asset ratio, return on asset, ukuran perusahaan, kurs, dan suku bunga merupakan variabel independen dalam penelitian. Sementara skor efisiensi teknis merupakan variabel dependennya. Skor efisiensi teknis digunakan sebagai variabel dependen karena terdiri dari efisiensi teknis murni dan skala efisiensinya.

Tabel 8.

Faktor-Faktor yang Memengaruhi Nilai Efisiensi Emiten Properti dan Real estate Pada ISSI Tahun 2016-2020

\begin{tabular}{lcc}
\hline Variabel & \multicolumn{2}{c}{ TE } \\
\cline { 2 - 3 } & Coeff & Prob \\
\hline C & 7.420088 & 0.0003 \\
DAR & -0.000748 & 0.2804 \\
ROA & 0.012316 & $0.0000^{*}$ \\
LNSIZE & -0.004367 & 0.7111 \\
LNKURS & -0.698164 & $0.0013^{*}$ \\
BIRATE & 0.019277 & 0.3028 \\
\hline
\end{tabular}

Sumber: Output Tobit (2021, diolah), * signifikan pada taraf nyata 5\%

Keterangan:

$\mathrm{DAR}_{\text {it }}$

$\mathrm{ROA}_{\mathrm{it}}$

: Debt to Asset Ratio

LNZISE $_{\text {it }} \quad$ : Ukuran perusahaan

LNKURS $_{\text {it }} \quad$ : Kurs

BIRATE $_{\text {it }} \quad$ : Suku bunga

Berdasarkan Tabel 8 dapat dilihat hasil analisis tobit yang menyatakan bahwa model yang digunakan pada analisis ini ulus dari kriteria Wald test dan Likelihood ratio test. Lulus kriteria Wald test ditunjukkan oleh nilai probabilitas variabel bebas yang lebih kecil dari taraf 92 
nyata 5\%. Sementara lulus kriteria uji Likelihood ratio ditunjukkan oleh nilai Likelihood ratio yang lebih kecil dibandingkan taraf nyata $5 \%$.

Hasil estimasi variabel DAR berpengaruh negatif namun tidak signifikan terhadap efisiensi emiten properti dan real estate. Hal ini sejalan dengan hasil penelitian Atta Mills et al. tahun 2020. Hasil penelitiannya menunjukkan bahwa DAR yang diamati tidak memiliki pengaruh yang signifikan dengan efisiensi perusahaan real estate.$^{20} \mathrm{Hal}$ ini mengungkapkan bahwa semua hal dianggap sama, peningkatan atau penurunan leverage oleh perusahaan real estate menyebabkan perubahan efisiensi yang tidak signifikan pada periode penelitian. Namun hasil penelitian ini berbeda dengan peenelitian yang dilakukan oleh Chen dan Li tahun 2017. Hasil tersebut mengungkapkan bahwa asset-liability ratio atau debt to asset ratio memiliki pengaruh yang negatif secara signifikan dengan efisiensi. Semakin tinggi rasio hutang atas aset yang dimiliki oleh emiten properti dan real estate dapat mengakibatkan leverage keuangan yang besar, dan kemudian mempengaruhi efisiensi operasional. ${ }^{21}$

Variabel rasio ROA memiliki pengaruh positif dan signifikan pada taraf nyata 5\%, cateris paribus. Hasil penelitian sejalan dengan hasil penelitian Atta Mills et al. tahun 2020 yang mengungkapkan bahwa ROA menunjukkan besaran keuntungan yang dapat diperoleh perusahaan dari asetnya. ROA mengukur seberapa efisien manajemen perusahaan real estate dalam menghasilkan pendapatan dari sumber daya atau aset mereka. ${ }^{22}$ Cateris paribus, terdapat hubungan positif antara profitabilitas dan efisiensi operasi. ${ }^{23}$ Semakin tinggi tingkat pengembalian aset atau ROA, semakin efisien perusahaan real estate dalam menggunakan aset. Hasil penelitian ini berbeda dengan hasil penelitian Abdullah tahun 2019 yang menunjukkan bahwa ROA memiliki pengaruh negatif yang tidak signifikan terhadap skor efisiensi teknis perusahaan real estate. ${ }^{24}$

Disisi lain, berdasarkan hasil estimasi pada Tabel 8 ukuran perusahaan memiliki pengaruh yang negatif namun tidak signifikan terhadap efisiensi teknis emiten properti dan real estate dengan taraf nyata $5 \%$, cateris paribus. Hasil ini tidak sejalan dengan penelitian $\mathrm{Ni}$, Nassir, dan FAH pada tahun 2018 yang menyatakan bahwa ukuran perusahaan memiliki pengaruh yang positif terhadap efisiensi perusahaan. ${ }^{25}$ Sedangkan pada penelitian Atta Mills et al. pada 2020 menunjukkan bahwa ukuran perusahaan memiliki hubungan yang negatif signifikan terhadap efisiensi perusahaan real estate. Adanya perbedaan ini dapat terjadi karena perusahaan besar seringkali lebih efisien dibandingkan perusahaan kecil sebab mereka dapat memperoleh keuntungan dari skala ekonomi ${ }^{26}$, akan tetapi perusahaan besar

\footnotetext{
${ }^{20}$ Ebenezer Fiifi Emire Atta Mills et al., "Dynamic Operating Efficiency and Its Determining Factors of Listed Real-Estate Companies in China," International Journal of Finance and Economics, no. June (2020): 1-25, doi:10.1002/ijfe.1965.

${ }^{21}$ Qiting Chen and Fengdan Li, "Empirical Analysis on Efficiency of Listed Real Estate Companies in China by DEA," IBusiness 09, no. 03 (2017): 49-59, doi:10.4236/ib.2017.93004.

22 Brijesh C Purohit, "Sustainability and Efficiency of Microfinance Institutions in South Asia," Theoretical and Applied Economics XXV, no. 4 (2018): 97-120.

${ }^{23}$ Chen and Li, "Empirical Analysis on Efficiency of Listed Real Estate Companies in China by DEA."

${ }^{24}$ Muhammad Ridhuan Bos Abdullah, Selamah Maamor, and Mohd Zaini Abdul Karim, "Efficiency of Real Estate Firms in Malaysia and Its Correlates," International Journal of Supply Chain Management 8, no. 1 (2019): 982-88.

${ }^{25} \mathrm{Ni}$, Nassir, and FAH, "Cash and Profit Efficient in Malaysia and South Korea Listed Company Using NonParametric DEA Method and Parametric Regression Method."

${ }^{26}$ Brent W. Ambrose, Michael J. Highfield, and Peter D. Linneman, "Real Estate and Economies of Scale: The Case of REITs," Real Estate Economics 33, no. 2 (2005): 323-50, doi:10.1111/j.15406229.2005.00121.x.
} 
Indah Fresma Sari, Jaenal Effendi

juga dapat mengalami diseconomies of scale. Perusahaan besar dapat menggunakan teknologi canggih dan memiliki kapasitas untuk mengeksplorasi dan tumbuh lebih subur sehingga tampak lebih efisien. ${ }^{27}$ Sementara itu, pertumbuhan ukuran yang luar biasa juga dapat mengakibatkan inefisiensi karena ada kecenderungan untuk salah mengalokasikan sumber daya meskipun ada keuntungan dari skala ekonomi. ${ }^{28}$

Variabel kurs berpengaruh negatif secara signifikan terhadap efisiensi emiten properti dan real estate. Hal tersebut didukung dengan penelitian Suyati pada tahun 2015. Nilai tukar rupiah terhadap dollar AS memiliki pengaruh yang signifikan terhadap return industri real estate sehingga pelemahan rupiah terhadap dollar AS (Amerika Serikat) akan berdampak pada return perusahaan khususnya pada perusahaan dengan pinjaman luar negeri dalam bentuk dollar. ${ }^{29}$ Pinjaman luar negeri adalah salah satu sumber daya keuangan yang digunakan oleh emiten properti dan real estate. Apabila rupiah memiliki volatilitas tinggi dan mengalami depresiasi yang tajam maka emiten-emiten properti dan real estate mungkin akan mengalami kerugian. Hal ini terjadi karena pendapatan yang diterima oleh emiten dalam rupiah, namun pembayaran kewajiban seperti pinjaman dan obligasi dibayarkan oleh emiten dalam mata uang asing. ${ }^{30}$

Lemahnya nilai tukar rupiah terhadap mata uang asing (dolar AS) akan berpengaruh terhadap emiten atau perusahaan yang menanggung beban hutang dalam bentuk dolar AS dan perusahaan yang melakukan transaksi impor bahan baku. Akibat yang terjadi jika nilai tukar melemah adalah perusahaan dapat menanggung beban hutang perusahaan yang lebih besar jika dinilai dengan rupiah. Selain itu, peningkatan beban biaya impor bahan baku dapat terjadi. Hal ini berdampak kepada penurunan laba perusahaan yang disebabkan besarnya biaya untuk pembayaran hutang dan biaya impor. ${ }^{31}$

Variabel suku bunga tidak berpengaruh secara signifikan terhadap efisiensi emiten properti dan real estate. Hal ini dimungkinkan oleh permasalahan disintermediasi perbankan terhadap efektivitas kebijakan moneter melalui jalur suku bunga dengan mekanisme transmisi jalur kredit. ${ }^{32}$ Pada Laporan Asesmen Transmisi Suku Bunga Kebjakan Kepada Suku Bunga Dasar Kredit (SBDK) Perbankan, SBDK tidak serta merta turun akibat penurunan suku bunga BI. Pergerakan SBDK masih sangat kaku dalam menanggapi penurunan suku bunga kebijakan. ${ }^{33} \mathrm{Hal}$ ini disebut dengan kekakuan atau rigiditas suku bunga. Proses transmisi

\footnotetext{
${ }^{27}$ Pang Tien Lieu, Tsai Lien Yeh, and Yung Ho Chiu, "Off-Balane Sheet Activities and Cost Inefficiency in Taiwan's Banks,” Service Industries Journal 25, no. 7 (2005): 925-44, doi:10.1080/02642060500134196.

${ }^{28}$ Fadzlan Sufian and Muzafar Shah Habibullah, "Developments in The Efficiency of The Thailand Banking Sector: A DEA Approach,” International Journal of Development Issues 9, no. 3 (2010): 226-45, doi:10.1108/14468951011073316.

${ }^{29}$ Sri Suyati, "Pengaruh Inflasi,Tingkat Suku Bunga Dan Nilai Tukar Rupiah/US Dollar Terhadap Return Saham Properti Yang Terdaftar Di Bursa Efek Indonesia," Serat Acitya-Jurnal Ilmiah UNTAG Semarang 4, no. 3 (2015): 70-86 ISSN: 2302-2752.

${ }^{30}$ Ibid.

31 Adrianna Syariefur Rakhmat, "Variabel Makroekonomi Sebagai Determinan Saham Properti," JSMA (Jurnal Sains Manajemen \& Akuntansi) 12, no. 1 (2020): 37-53.

${ }^{32}$ Perry Warjiyo, Bank Indonesia Bank Sentral Republik Indonesia : Sebuah Pengantar, ed. J.D. Parera, Bank Indonesia, 1st ed. (Jakarta: Pusat Pendidikan dan Studi Kebanksentralan (PPSK) BI, 2004).

33 BI, "Asesmen Transmisi Suku Bunga Kebijakan Kepada Suku Bunga Dasar Kredit Perbankan,” 2021, https://www.bi.go.id/. 
suku bunga tidak terjadi segera serta memiliki tenggat (gap) waktu, khususnya sebab kondisi internal perbankan dalam pengelolaan aset serta kewajibannya. ${ }^{34}$

Sektor properti dan real estate khususnya perumahan sangat bergantung terhadap suku bunga KPR yang diberikan oleh bank. Pembelian rumah di Indonesia masih didominasi oleh pembiayaan KPR yaitu sebesar 76.02 persen pada triwulan III 2020. ${ }^{35}$ Dengan adanya rigiditas suku bunga, maka pergerakan suku bunga BI belum mampu memengaruhi SBDK perbankan termasuk dalam menggerakan suku bunga KPR. Oleh karena itu penurunan suku bunga BI belum tentu dapat membangkitkan permintaan masyarakat terhadap perumahan. Hal ini menjadi penghambat tumbuhnya sektor riil properti dan real estate. ${ }^{36}$

\section{PENUTUP}

Berdasarkan hasil analisis efisiensi teknis emiten properti dan real estate yang terdaftar di ISSI pada tahun 2016-2020, tidak ada satupun emiten yang konsisten mencapai nilai efisiensi teknis sempurna (skor efisiensi sama dengan 1). Hal serupa juga terjadi pada hasil analisis efisiensi teknis murni maupun skala efisiensi. Pada tahun 2016 terdapat 6 emiten properti dan real estate yang memiliki efisiensi teknis dengan nilai sama dengan 1, sedangkan pada tahun 2017 hingga 2019 masing masing terdapat 2 emiten yang mencapai skor efisiensi sama dengan 1 . Sementara itu, pada tahun 2020 hanya ada 1 emiten yang mencapai nilai efisiensi teknis sempurna. Berdasarkan 4 variabel independen yang digunakan untuk mengetahui faktor-faktor yang memengaruhi tingkat efisiensi emiten properti dan real estate pada ISSI tahun 2016-2020, variabel Return on Asset (ROA) memiliki berpengaruh positif secara signifikan terhadap nilai efisiensi emiten. Sedangkan kurs (LNKURS) memiliki pengaruh yang negatif secara signifikan terhadap nilai efisiensi emiten. Sementara itu, variabel Debt to Asset Ratio (DAR), ukuran perusahaan LNSIZE, dan suku bunga (BIRATE) tidak berpengaruh secara signifikan terhadap tingkat efisiensi emiten.

\section{DAFTAR PUSTAKA}

Abdullah, Muhammad Ridhuan Bos, Selamah Maamor, and Mohd Zaini Abdul Karim. "Efficiency of Real Estate Firms in Malaysia and Its Correlates." International Journal of Supply Chain Management 8, no. 1 (2019): 982-88.

Ambrose, Brent W., Michael J. Highfield, and Peter D. Linneman. "Real Estate and Economies of Scale: The Case of REITs." Real Estate Economics 33, no. 2 (2005): 323-50. doi:10.1111/j.1540-6229.2005.00121.x.

Assaf, A. George, Carlos Barros, and Ricardo Sellers-Rubio. "Efficiency Determinants in Retail Stores: A Bayesian Framework." Omega 39, no. 3 (2011): 283-92. doi:10.1016/j.omega.2010.07.005.

Atta Mills, Ebenezer Fiifi Emire, Mavis Agyapomah Baafi, Fangbiao Liu, and Kailin Zeng. "Dynamic Operating Efficiency and Its Determining Factors of Listed Real-Estate Companies in China." International Journal of Finance and Economics, no. June (2020): 125. doi:10.1002/ijfe.1965.

BEI. "Klasifikasi Industri Baru BEI (IDX Industrial Classification)," 2021. https://www.idx.co.id/.

\footnotetext{
${ }^{34}$ Perry Warjiyo, Mekanisme Transmisi Kebijakan Moneter di Indonesia (Jakarta: Pusat Pendidikan dan Studi Kebanksentralan (PPSK) BI, 2004).

${ }^{35}$ BI, "Survei Harga Properti Residensial Triwulan III-2020," 2020, https://www.bi.go.id/.
} 
Indah Fresma Sari, Jaenal Effendi

___. "Panduan IDX Industrial Classification," 2021. https://www.idx.co.id/.

BI. "Asesmen Transmisi Suku Bunga Kebijakan Kepada Suku Bunga Dasar Kredit Perbankan," 2021. https://www.bi.go.id/.

___. "Survei Harga Properti Residensial Triwulan III-2020," 2020. https://www.bi.go.id/.

BPS. "Produk Domestik Bruto Indonesia Triwulanan 2016-2020," 2020. https://www.bps.go.id.

Bursa Efek Indonesia. "Laporan Informasi Atau Fakta Material Dampak Pandemi COVID-19 LPCK," 2020. https://www.idx.co.id/.

_- - "Laporan Informasi Atau Fakta Material Dampak Pandemi COVID-19 PWON," 2020. https://www.idx.co.id/.

Chen, Qiting, and Fengdan Li. "Empirical Analysis on Efficiency of Listed Real Estate Companies in China by DEA." IBusiness 09, no. 03 (2017): 49-59. doi:10.4236/ib.2017.93004.

Cooper, William W, Lawrence M Seiford, and Kaoru Tone. Introduction to Data Envelopment Analysis and Its Uses: With DEA-Solver Software and References. 1st ed. New York: Springer, 2006. doi:10.1007/0-387-29122-9.

Kasmir. Analisis Laporan Keuangan. Jakarta: RajaGrafindo Persada, 2012.

Kusumo, Wilyanto Kartiko, and Abdul Karim. "Analisis Efisiensi Perbankan Syariah Dengan Metode Stochastik Frontier Approach (SFA) : Studi Kasus Pada Bank Umum Syariah, Unit Usaha Syariah Dan Layanan Syariah (Offece Chanelling) Di Indonesia." SOLUSI 13, no. 2 (2014): 123-51.

Lieu, Pang Tien, Tsai Lien Yeh, and Yung Ho Chiu. "Off-Balane Sheet Activities and Cost Inefficiency in Taiwan's Banks." Service Industries Journal 25, no. 7 (2005): 925-44. doi:10.1080/02642060500134196.

Mirghaderi, S A H, A Sheikh Aboumasoudi, Najafabad Branch, Received January, and Accepted June. "The Ranking of Financial Efficiency of Companies Accepted in Stock Exchange of Tehran between 2013 to 2016 through Financial Ratio Approach and Using DEA" 5, no. 3 (2017).

Ni, Soh Wei, Annuar Md Nassir, and Cheng Fan FAH. "Cash and Profit Efficient in Malaysia and South Korea Listed Company Using Non-Parametric DEA Method and Parametric Regression Method." International Journal of Economics and Management 12, no. Special Issue 2 (2018): 711-29.

OJK. "Peraturan Otoritas Jasa Keuangan Nomor 35/POJK.04/2017 Tentang Kriteria Dan Penerbitan Daftar Efek Syariah," 2017.

- _ - "Peraturan Otoritas Jasa Keuangan Nomor 17/POJK.04/2015 Tentang Penerbitan Persyaratan Efek Syariah Berupa Saham Emiten Syariah," 2015.

Purohit, Brijesh C. "Sustainability and Efficiency of Microfinance Institutions in South Asia." Theoretical and Applied Economics XXV, no. 4 (2018): 97-120.

Rakhmat, Adrianna Syariefur. "Variabel Makroekonomi Sebagai Determinan Saham Properti." JSMA (Jurnal Sains Manajemen \& Akuntansi) 12, no. 1 (2020): 37-53.

Sabiti, Mustica Bintang, Jaenal Effendi, and Tanti Novianti. "Efisiensi Asuransi Syariah Di Indonesia Dengan Pendekatan Data Envelopment Analysis." Al-Muzara'ah 5, no. 1 (2018): 69-87. doi:10.29244/jam.5.1.69-87.

Soetanto, Tessa V., and Liem Pei Fun. "Performance Evaluation of Property and Real Estate Companies Listed on Indonesia Stock Exchange Using Data Envelopment Analysis." Jurnal Manajemen Dan Kewirausahaan 16, no. 2 (2014): 121-29. doi:10.9744/jmk.16.2.121-130. 
Sufian, Fadzlan, and Muzafar Shah Habibullah. "Developments in The Efficiency of The Thailand Banking Sector: A DEA Approach." International Journal of Development Issues 9, no. 3 (2010): 226-45. doi:10.1108/14468951011073316.

Suyati, Sri. "Pengaruh Inflasi,Tingkat Suku Bunga Dan Nilai Tukar Rupiah/US Dollar Terhadap Return Saham Properti Yang Terdaftar Di Bursa Efek Indonesia." Serat Acitya-Jurnal Ilmiah UNTAG Semarang 4, no. 3 (2015): 70-86 ISSN: 2302-2752.

Triyono. "Pengembangan Perusahaan Pada Era Krisis Ekonomi Berkepanjangan." Jurnal Ekonomi Dan Bisnis 2, no. 1 (2005): 1-10.

Warjiyo, Perry. Bank Indonesia Bank Sentral Republik Indonesia : Sebuah Pengantar. Edited by J.D. Parera. Bank Indonesia. 1st ed. Jakarta: Pusat Pendidikan dan Studi Kebanksentralan (PPSK) BI, 2004.

- - - Mekanisme Transmisi Kebijakan Moneter di Indonesia. Jakarta: Pusat Pendidikan dan Studi Kebanksentralan (PPSK) BI, 2004.

Wibowo, Edi. "Analisis Penentuan Saham Yang Akan Dibeli Suatu Tinjauan Umum." Jurnal Ekonomi Dan Kewirausahaan 11, no. 1 (2011): 151-58.

Widhiatmoko, Sidharta Wisnu, and Vaya Juliana Dillak. "Pengaruh Inflasi, Kurs Valuta Asing, Dan Tingkat Suku Bunga SBI Terhadap Return Saham (Studi Pada Perusahaan Sektor Properti Yang Terdaftar Di Bursa Efek Indonesia Tahun 2013-2016)." In EProceedings of Management. Telkom University, 2018.

$\mathrm{Xu}, \mathrm{Zhi}$, and Ping Shi. "Evaluation of Relative Efficiency of Science and Technology Input in China Based on DEA." Studies in Science of Science 23, no. 4 (2005): 481-84. 